\title{
Corporate Governance and Intellectual Capital on Firm Value of Banking Sector Companies Listed at Indonesia Stock Exchange in Period 2008-2012
}

\author{
Jauhar Arifin* \\ Department of Business Administration, College of Administrative Sciences (STIA) Tabalong, South Kalimantan, \\ Indonesia
}

\section{Abstract}

This study was aimed to assess the influence of corporate governance and intellectual capital on the firm value of Bank Sector companies listed at Indonesia Stock Exchange in 2008-2012. The unit data of Indonesia Stock Exchange is represented by the audited company's financial statements and historical data of stock prices in Indonesia Stock Exchange from the year of 2008 to 2012. Companies sampled in the study only companies which meet the sampling criteria. Data analysis used Generalized Structured Component Analysis (GSCA). Result of research indicates that Corporate Governance does not have significant influence on Intellectual Capital. It seems that Intellectual Capital does not have significant influence on Corporate Governance either. However, Corporate Governance and Intellectual Capital are significantly influences the firm value.

Keywords: Corporate Governance, Intellectual Capital, Firm Value

\section{INTRODUCTION}

The era of global economy challenges companies to be more competitive to lead to knowledge-based resources as a major factor in maintaining a competitive advantage [1]. With the advent of the knowledge-based economy, intellectual capital compared to physical and financial capital becomes a major factor in creating corporate value and maintain competitive advantage [2]. The emergence of "new economy" that is principally driven by developments in information technology and science, has also sparked growing interest in the disclosure of intellectual capital $[3,4]$.

The issue of corporate governance started to be discussed more since the occurrence of the various scandals that indicate poor corporate governance. Enron and WorldCom scandals in the US, Marconi in Britain, and Royal Ahold in the Netherlands have made financial experts to pay more attention to the role of corporate governance. Institutional investors begin to evaluate the role of corporate governance in their investment policies. In Indonesia, the number of troubled banks case (as in the case of Bank Lippo, Bank Summa, Bank BNI, and Bank Century) due to unhealthy banking practices and overriding the principles of corporate governance has been going on a lot [5].
The entry of foreign companies into the Indonesian market demands domestic enterprises to further improve the value and performance to face increasing competition. In the improvement process, companies need relevant information on the measured elements not only tangible assets, but also intangible assets in order to disclose the value and performance. In addition to improving the disclosure of financial statements and the disclosure of intellectual capital, a company also needs to carry out the implementation and management of good corporate governance [6].

We have acknowledged the influence of intellectual capital to create value and competitive advantage, but the exact size for the intellectual capital is still being developed. Public [7] suggests an indirect measurement of the intellectual capital by measuring the efficiency of the benefit generated by the company's intellectual ability (Value Added Intellectual Coefficient - VAIC).

In developing countries, such as in Indonesia, banking industry is very important in the process of economic development. The selection of bank as a research object because (a) bank is a business sector that is intellectually intensive [8]; (b) bank also includes the service sector, where customer service is very dependent on the intelligence of

\footnotetext{
Correnspondence Address:

Jauhar Arifin

Email : jauhar58@yahoo.com

Address : Komplek Stadion Olah Raga Saraba Kawa Pembataan Tanjung-Tabalong, 71571, South Kalimantan
} 
human capital; (c) bank is an institution known as a risk-taking entity [10]; (d) bank in conducting its operational activities is more associated with risk when compared to manufacturing companies and other enterprises; and (e) banking is considered to have a high level of regulation as stipulated by Bank Indonesia Regulation.

Research on the influence of corporate governance and intellectual capital on firm value has not been done. Similar research in Malaysia on Five Industries (Information Technology, Consumer Products, Industrial Products, Trade / Services and Financial) involved 150 samples and used analytical tools Ordinary Least Square (OLS) [10]. The results of the study show that the disclosure of intellectual capital in the company is $72.6 \%$, but the level of disclosure of intellectual capital between Malaysian companies are still relatively low at around $3.45 \%$. Besides, it was also found that the corporate governance has a positive and significant relationship on the level of intellectual capital, while the size of the Audit Committee does not have a significant relationship with the disclosure of intellectual capital [10].

Similarly, a study on Intellectual Capital and Board Performance Characteristics of GCC Banks in the 2008 to 2010 periods, multiplied by 3 years, equal to 147 observers [2]. The results show that the performance of Intellectual Capital listed on the GCC is low, and the proportion of independent directors has a significant negative correlation with the performance of Intellectual Capital registered in the Arabian Gulf Cooperation Council (GCC).

Research on the effect of accumulation of intellectual capital and corporate governance to corporate value toward the electronics company listed in Taiwan shows that there was a positive and significant effect of the accumulation of intellectual capital and corporate governance of the company value [11]. Another study shows that Intellectual Capital enhances the ability of AUB (American University of Baerut) and there is a significant relationship between corporate governance and intellectual capital, but the relationship between intellectual capital and corporate governance at AUB is weak (American University of Baerut) [12]. Thus the aim of this study was to assess the influence of corporate governance and intellectual capital on the Firm Values of Bank Sector companies that listed in the Jakarta Indonesia Stock Exchange (IDX) in the period 2008-2012.

\section{RESEARCH METHOD}

The research is explanatory research, conducted with a purpose to explain the causal relationship between the variables through hypothesis testing [13]. Seen from the legality of data, this study is ex post facto, because the research data come from financial statements and annual reports published and used by researchers as they are without changes. Seen from data collection method, this study is observation, because the data can only be read and gathered from financial statements and annual reports published in accordance with variables to be studied.

\section{Data Collection}

The unit of analysis is the companies in banking sector listed on the Indonesia Stock Exchange by retrieving data from ICMD, financial statements, and annual reports of the companies. The research location is companies in banking sector located operating in the territory of the Republic of Indonesia and listed on the Indonesia Stock Exchange in 2008-2012 periods. Sample was chosen through purposive sampling, under the following criteria:

1. The company listed on the Indonesia Stock Exchange during 2008 to 2012

2. The company whose shares are actively traded on the Indonesia Stock Exchange during the study period

3. The company has information about publication of financial statements and annual reports on a regular basis during the period 2008-2012.

4. The company must implement corporate governance, consists of a proportion of the Audit Committee, and the proportion of independent commissioner.

5. Each annual report and financial statements must contain disclosure of intellectual capital.

Based on the above criteria, there were 26 companies meeting the criteria. As many as 9 companies have not been listed on the Jakarta Stock Exchange since 2008. The number of samples can be seen in Table 1 . Samples were companies in banking sector listed on the Stock Exchange until 2007 and are still active in 2008 and 2012 with the complete continuous annual report, financial statements, and ICMD (Indonesia Capital Market Directory) from 2008 to 2012. The number of sample is as much as 26 for 5 years, equal to 130 samples. 
The type of data is quantitative and secondary data. Data for this study were obtained from the financial statements and annual report downloaded from the site www.idx.co.id. The data used in the research is documentation, by collecting, recording, and calculating data related to the study.

Tabel 1. Sample of Companies in Banking Sector

\begin{tabular}{cll}
\hline No & Code & \multicolumn{1}{c}{ Bank Companies } \\
\hline 1 & AGRO & Bank Rakyat Indonesia Agro Niaga Tbk. \\
2 & BABP & Bank ICB Bumi Putera Tbk. \\
3 & BACA & Bank Capital Indonesia Tbk. \\
4 & BBKP & Bank Bukopin Tbk. \\
5 & BBNI & Bank Negara Indonesia (Persero) Tbk. \\
6 & BBNP & Bank Nusantara Parahyangan Tbk. \\
7 & BBRI & Bank Rakyat Indonesia (Persero) Tbk. \\
8 & BCIC & Bank Mutiara Tbk. \\
9 & BDMN & Bank Danamon Indonesia Tbk. \\
10 & BEKS & Bank Pundi Indonesia Tbk. \\
11 & BKSW & Bank Kesawan Tbk. \\
12 & BMRI & Bank Mandiri (Persero) Tbk. \\
13 & BNBA & Bank Bumi Artha Tbk. \\
14 & BNGA & Bank CIMB Niaga Tbk. \\
15 & BNII & Bank Internasional Indonesia Tbk. \\
16 & BNLI & Bank Permata Tbk. \\
17 & BSWD & Bank Swadesi Tbk. \\
18 & INPC & Bank Artha Graha International Tbk. \\
19 & MCOR & Bank Windu Kentjana International Tbk. \\
20 & NISP & Bank NISP OCBC Tbk. \\
21 & SDRA & Bank Himpunan Saudara Tbk. \\
22 & BVIC & Bank Victoria Internasional \\
23 & MAYA & Bank Mayapada Internasional \\
24 & MEGA & Bank Mega Tbk \\
25 & PNBN & Bank Pan Indonesia Tbk \\
26 & BBCA & Bank Central Asia Tbk \\
\hline Sumber Data Processed 2014
\end{tabular}

Sumber: Data Processed 2014

\section{Operational Variable}

\section{Corporate Governance}

Corporate governance is a set system of rules to direct and control the company for the the interests of shareholders. Corporate governance in this study was measured using indicator ofproportion of Independent Audit Committee and Independent Commissioner.

\section{Independent Audit Committee}

The establishment of Audit Committee is to empower the commissioner in conducting surveillance function. An effective audit committee will help create transparency and quality of financial reporting, compliance to applicable regulations, and adequate internal controls [14]. The Audit Committee is another mechanism that affects internal corporate governace to improve the quality of corporate financial management and performance [15]. In this study, the proportion of Independent Audit
Committee is a percentage of independent audit committee members held by the company. This measurement refers to following formula [14].

Independent Audit Committee Proportion

$=\frac{\sum \text { Independent Audit Committee }}{\sum \text { Audit Committee }}$

$\times 100 \%$

Independent Commissioners

In the framework of the implementation of good corporate governance, the Stock Exchange requires listed companies to have an independent commissioner. Independent commissioner serves to provide an objective and independent assessment that can be the consideration of the Board in decision-making [16]. Independent commissioner is the best position to carry out the monitoring functions in order to create firms with good corporate governance. The inclusion of commissioners who come from outside the company (independent commissioner) increase the effectiveness of the Board in overseeing management to prevent fraudulent financial statements [17]. The proportion of Independent Commissioner in this study is the percentage of the number of commissioners who come from outside the company (independent) to the overall number of commissioners [18].

Independent Commission Proportion

$=\frac{\sum \text { Independent Commission }}{\sum \text { Commission }} \times 100 \%$ Intellectual Capital

Intellectual capital in this research is the intellectual capital performance as measured by value added created by the indicator of Value Added Capital Employed (VACA), Value Added Human Capital (VAHU), and Structural Capital Value Added (STVA). The combination of these three value added is symbolized by the name of VAIC Pulic Model [19] with three indicators:

\section{Value Added Capital Employed (VACA)}

VACA is a comparison between the value added (VA) with physical capital works (CA). This ratio is an indicator for the VA made by a unit of physical capital [19], with the following formula:

$$
\mathrm{VACA}=\frac{\mathrm{VA}}{\mathrm{CA}}
$$

Value Added Human Capital (VAHU)

VAHU is how much VA formed by workers' expenses. The relationship between VA and HC indicates the ability of $\mathrm{HC}$ to make a value on a company [19], with the following formula: 


$$
\mathrm{VAHU}=\frac{\mathrm{VA}}{\mathrm{HC}}
$$

Structural Capital Value Added (STVA)

STVA shows the contribution of structural capital (SC) in the formation of values. SC is VA subtracted by HC. HC contributes to the formation of greater value contribution SC [19], with the following formula:

Description:

$$
\text { STVA }=\frac{\mathrm{SC}}{\mathrm{VA}}
$$

VA: total sales and other income minus the burden and costs (other than personnel expenses)

CA: funds available (equity, net income)

HC: personnel expenses

SC: value Added minus human capital (personnel expenses)

Those ratios are calculation of intellectual ability of a company. This formulation is the number of coefficients previously mentioned. The result is a new and unique indicator, VAIC. VAIC indicates the ability of intellectual capital of organization that can also be considered as BPI (Business Performance Indicators).

\section{Firm Value}

Firm value is a specific condition that achieved by a company as a description of public confidence in the company after going through several years, i.e. since the company was founded until now. Firm value in this study was measured using the following indicators:

The ratio of the market price and the book value or the Market-to-book ratio (MBR)

This ratio is a ratio that measures the value of the company given by the financial market to the management and organization of the company that continues to grow [20]. Ratio also shows a comparison of the market price of equity to book value of equity. This measurement is formulated as follows:

$$
\begin{aligned}
& \text { Market }- \text { to }- \text { book ratio }(M B R) \\
& =\frac{\text { market price of equity }}{\text { book value of equity }}
\end{aligned}
$$

\section{Tobin's $Q$}

Tobin's $Q$ is a more accurate measure on the effectiveness of management in utilizing resources in its economic power [20]. Tobin's $Q$ in this study is the market value of equity plus the book value of debt divided by the book value of equity plus the book value of the debt.

$$
\begin{aligned}
& \text { Tobin's } Q \\
& =\frac{\text { Market Value Equity }+B V \text { of Debt }}{\text { Book Value Equity }+B V \text { of Debt }}
\end{aligned}
$$

\section{Closing Price}

Closing Price is the final price of shares traded on a particular trading day (can be daily, weekly, monthly, and quarterly), which is included in each annual report (quarterly). The closing price is the the most up-to-date price information in assessing the stock until trading is open again on the next trading day [21]. The price of a stock reflects all information known by the public about the expected future gains from the stock [22]. Closing Price refers to the size of the formula [23]:

$$
\text { Closing Price }=\log _{N} \boldsymbol{C P}
$$

\section{Inferential Statistical Analysis}

Methods of data analysis used in this study, i.e. the descriptive and statistical inferensial analysis i.e. Generalized Structured Component Analysis (GSCA). As for consideration using the program GSCA in this study because the type of the variables examined in addition to the replectif variable is also a formative variables with a small number of samples. While the GSCA is an analysis tool that can be used to analyze the various types of variables are variables that either reflectif or formative variables.

\section{RESULTS}

\section{Corporate Governance Variable}

The relationship of indicators of corporate governance variable $\left(X_{1}\right)$ with indicators proportion of Independent Audit Committee and Independent Commissioner can be interpreted as follows. The proportion of Independent Audit Committee $\left(X_{1.1}\right)$ was 0.25 minimum value and maximum 1 ; the average proportion of Committees Independent Audit ( $\left.X_{1.1}\right) 0.56$ or $56 \%$. Thus, the average proportion of independent audit committees in companies in the banking sector listed on the Stock Exchange in 2008 to 2012 was $56 \%$.

According to the Decision of the Directors Board of Jakarta Stock Exchange Kep-305/BEJ/072004, the Audit Committee is responsible for providing independent professional opinion to the Board of Commissioners. The reports submitted by the directors to the Board of Commissioners and identifying matters require the attention of the Board of Commissioners. Independent 
Commissioners in the Audit Committee is expected to further improve the quality of supervision to the management in running the company and compliance with the regulations. They also expected to be more efficient in the system of reporting to the Board of Commissioners, because of the Independent Audit Committee can deliver findings to the board of commissioners. A company that has Independent Audit Committee will have lower debt financing costs [26], while other expert explained that market reacted more favorably to the earnings report after the establishment of the Audit Committee [27]. A study found a negative linear relationship between the independent audit committee with earnings management; further, it also suggested a need of independent board composed of CEOs to be more effective in the process of monitoring the company's financial accounting [28].

The proportion of Independent Commissioners $\left(X_{1.2}\right)$ had a minimum value of 0.14 , maximum of 0.58 and average of $58 \%$, This shows that in 2008 to 2013, companies in banking sector listed on the Stock Exchange and the research samples have average independent board members by 0.58 , or $58 \%$ of the number of commissioners in the company. In accordance with Law Number 40 of 2007 on Limited Liability Companies, Article 120 Paragraph 1 states that the Articles of Association of a Company can be set up for 1 (one) or more independent commissioner and 1 (one) Commissioner Envoy. Meanwhile, according to the Decision of the Board of Directors Jakarta Stock Exchange Kep305/BEJ/07-2004, Independent Commissioner of the Company must have at least $30 \%$ from the members of the Board of Commissioners. Thus, the average proportion of independent commissioner in Board of Commissioner in banking sector companies already comply with the provisions of Law No. 40 of 2007 and Decree of the Board of Directors of the Jakarta Stock Exchange Kep-305/BEJ/07-2004.

Independent commissioner is a party that does not have access to fraud, but has the right to obtain financial information of the company. For the independent commissioner, performance and value of a good company is the expected goals in the future so that the independent board surveillance on management performance is needed. A large proportion of independent directors will improve financial performance and corporate value in the future.

\section{Intellectual Capital Disclosure}

Disclosure of Intellectual capital variable $\left(\mathrm{X}_{2}\right)$ has the following indicators: Value added Capital Employed (VACA) $\left(X_{2.1}\right)$, Human Capital Coefficient (VAHU) $\left(X_{2.2}\right)$, and Structral Capital Coefficient (STVA) ( $X_{2.3}$ ). Descriptive analysis results on each indicator show that Value Added Capital Employed (VACA) had -0.37 minimum and 0.89 maximum valueand an average of 0.21 . This illustrates that the average banking sector companies listed on the Stock Exchange has been utilizing the capital employed, whose added value can be created by one unit of physical capital. If one unit of CE (Capital Employed) produces greater returns than other companies, it means the company better utilizes its CE [19].

Based on the concept of Resources Theory (RBT), in order to compete with other companies, a company needs asset management capabilities in both physical assets and intellectual assets. VACA is a form of company's ability to manage its resources in the form of capital assets. With good management of capital assets, it is believed that the company can increase the market value and performance. Thus, the utilization of better intellectual capita disclosure is part of the intellectual capitaldisclosure of a company.

Human Capital Employed Coefficient (VAHU) has a minimum value of 0.02 , a maximum value of 5.77 , and an average of 1.22 . Thus, the banking sector companies listed on the Stock Exchange in 2008-2012 had average of 1.22 funds expended for labor to create value added. The relationship between VA with Human Capital Employed indicates the ability to create value in the company.

Based on the concept of Resources Theory (RBT), in order for companies to compete, high quality human resources are needed. Additionally, companies must be able to manage the quality of resources to the maximum in order to create value added and competitive advantages that may ultimately improve the financial performance and corporate value.

Structural Capital Coefficient (STVA) has a minimum value of 7.80 and a maximum of -5.56 , and an average of -0.25 . This shows -0.25 contribution of structural capital (SC) in value creation. STVA measures SC needed to produce 1 rupiah of VA and is an indication of how the success of the SC in value creation. SC is not a measure independent as $\mathrm{HC}$ in the value creation process. That is, the greater the contribution of $\mathrm{HC}$ in value creation, the smaller the contribution of 
$\mathrm{SC}$ in this regard. Further, SC is VA subtracted by $\mathrm{HC}[19]$.

\section{Firm Value Variable}

Variable of Firm Value $\left(Y_{2}\right)$ in this study was measured by three indicators, namely the Marketto-book ratio (MBR $\left.\left(Y_{2.1}\right)\right)$, Tobin's $Q\left(Y_{2.2}\right)$, and the Closing Price $\left(Y_{2.3}\right)$. Market-to-book has a minimum value of -1.74 , a maximum value of 8.55 , and average of 1.81 . This shows that the banking sector companies listed in the Stock Exchange in 2008 to 2012 have stock value 1.81 times greater than the book value of equity held by the company. This ratio measures the value of firm valuegiven by financial market to the management and organization of the company that continues to grow [29]. This ratio also shows a comparison of the market price of equity to book value of equity.

Tobin's $Q$ has a minimum value of 0.14 , a maximum value of 1.70 , and an average of 0.52 . This indicates that the market value of the company's assets divided by the cost of replacement is 0.52 . A company with a high $Q$ ratio tends to have attractive investment opportunities or competitive advantages, which aresignificantly superior (or both) [30]. Tobin's Q average value of 0.52 indicates the feasibility to invest in banking sector companies listed in the Jakarta Stock Exchange.

Closing Price 5.1 has a minimum value of 1.69, a maximum value of 4.02 , and an average value of 2.79. This shows that the banking sector companies listed on the Stock Exchange in 20082012, in average have good Closing Price and good prospects. Closing Price is the final price at which securities are traded on a given trading day [31]. The Closing Price is the most up-to-date assessment of securities to trading resumed on the next trading day, the price of a stock reflects all known information about the expected profit in the future of the stock [22].

\section{Confirmatory Factor Analysis}

Table 1 show that the indicator of the proportion of independent audit committees $\left(X_{1.1}\right)$ has a loading/weight value of 0.368 and the proportion of independent directors $\left(X_{1.2}\right)$ has a value of loading/weight value of 0.368 . This indicates that the proportion of independent audit committees $\left(X_{1.1}\right)$ and the proportion of independent directors $\left(X_{1.2}\right)$ have the same contribution weight influence on Corporate Governance.
Table 1. Loading Factor Indicator of Corporate Governance Variable

\begin{tabular}{ccc}
\hline No. & Indicator & Loading/Weight \\
\hline 1. & $\mathrm{X}_{1.1}$ & 0.368 \\
2. & $\mathrm{X} 1.2$ & 0.368 \\
\hline
\end{tabular}

Table 2 shows that indicator of Human Capital Coefficient (VAHU) $\left(\mathrm{X}_{2.2}\right)$ has a value of loading/ weigth of 0.461 and Value Added Capital Employed (VACA) $\left(\mathrm{X}_{2.1}\right)$ has a value of loading/ weigth of 0.419 , and Structural Capital Value Added $\left(X_{2.3}\right)$ has a value of loading/weigth of 0.368 . This indicates that the indicator of Value Added Human Capital (VAHU) $\left(\mathrm{X}_{2.2}\right)$ is a dominant indicator that explains the variable of intellectual capital, followed by Value Added Capital Employed (VACA) ( $\mathrm{X}_{2.1}$ ) and Structural Capital Value Added ( $\mathrm{X}_{2.3}$ ) ith lowest contribution to the Intellectual Capital.

Table 2. Loading Factor Indicator of Intellectual Capital

\begin{tabular}{ccc}
\multicolumn{3}{c}{ Variable } \\
\hline No. & Indicator & Loading/Weight \\
\hline 1. & $\mathrm{X}_{2.1}$ & 0.419 \\
2. & $\mathrm{X}_{2.2}$ & 0.461 \\
3. & $\mathrm{X}_{2.3}$ & 0.368 \\
\hline
\end{tabular}

Table 3 shows that the indicator of $\operatorname{MBR}\left(\mathrm{Y}_{2.1}\right)$ has a dominant loading/weight value of -0.450 , Closing Price $\left(\mathrm{Y}_{2.3}\right)$ has a loading / weight value of 0.420, and Tobin's $Q\left(Y_{2.2}\right)$ has a loading/weight value of 0.414 . This indicates that $\operatorname{MBR}\left(Y_{2.1}\right)$ is is a dominant indicator and Closing Price $\left(Y_{2.3}\right)$ affects Firm value, followed by Tobin's $Q\left(Y_{2.2}\right)$ having the lowest contribution to the Firm Value.

Table 3. Loading Factor Indicator of Firm Value Variable

\begin{tabular}{ccc} 
No. & Indicator & Loading/Weight \\
\hline 1. & $Y_{1.1}$ & 0.450 \\
2. & $Y_{1.2}$ & 0.414 \\
3. & $Y_{1.3}$ & 0.420 \\
\hline
\end{tabular}

GSCA Analysis

The results of the analysis provide FIT value of 0.315 or variables included in the model are able to explain the diversity or the phenomena of $31.5 \%$, the rest $(68.5 \%)$ is explained by variables not included in the model (Table 4). Testing the hypothesis in this study is done by looking at the paths on the significant structural model. The pathways of significant relationships (influence) can be seen in the coefficient path using the test (t-test). The results of research hypothesis testing are as follows (Fig. 1):

1. Corporate governance has non-significant effect on intellectual capital.

2. Intellectual capital disclosure has nonsignificant effect on corporate governance. 
3. Corporate governance has significant negative effect on firm value.

4. Intellectual capital disclosure has significant effect on firm value.

5. Intellectual capital disclosure has significant effect on firm value.
Table 4. Estimation and $P$ value of each path coefficient

\begin{tabular}{|l|c|c|c|c|c|}
\hline \multicolumn{6}{|c|}{ Path Coefficient } \\
\hline & Estimate & SE & CR & $\mathbf{p}$ & Note \\
\hline $\mathbf{X 1 - > X 2}$ & 0.057 & 0.052 & 1.08 & 0.282 & Non significant \\
\hline $\mathbf{X 2 - > \mathbf { X }}$ & 0.059 & 0.045 & 1.31 & 0.193 & Non significant \\
\hline $\mathbf{X 1 - > Y 1}$ & -0.164 & 0.032 & 5.1 & 0.000 & Significant \\
\hline $\mathbf{X 2 - > Y 1}$ & 0.418 & 0.032 & 12.98 & 0.000 & Significant \\
\hline
\end{tabular}

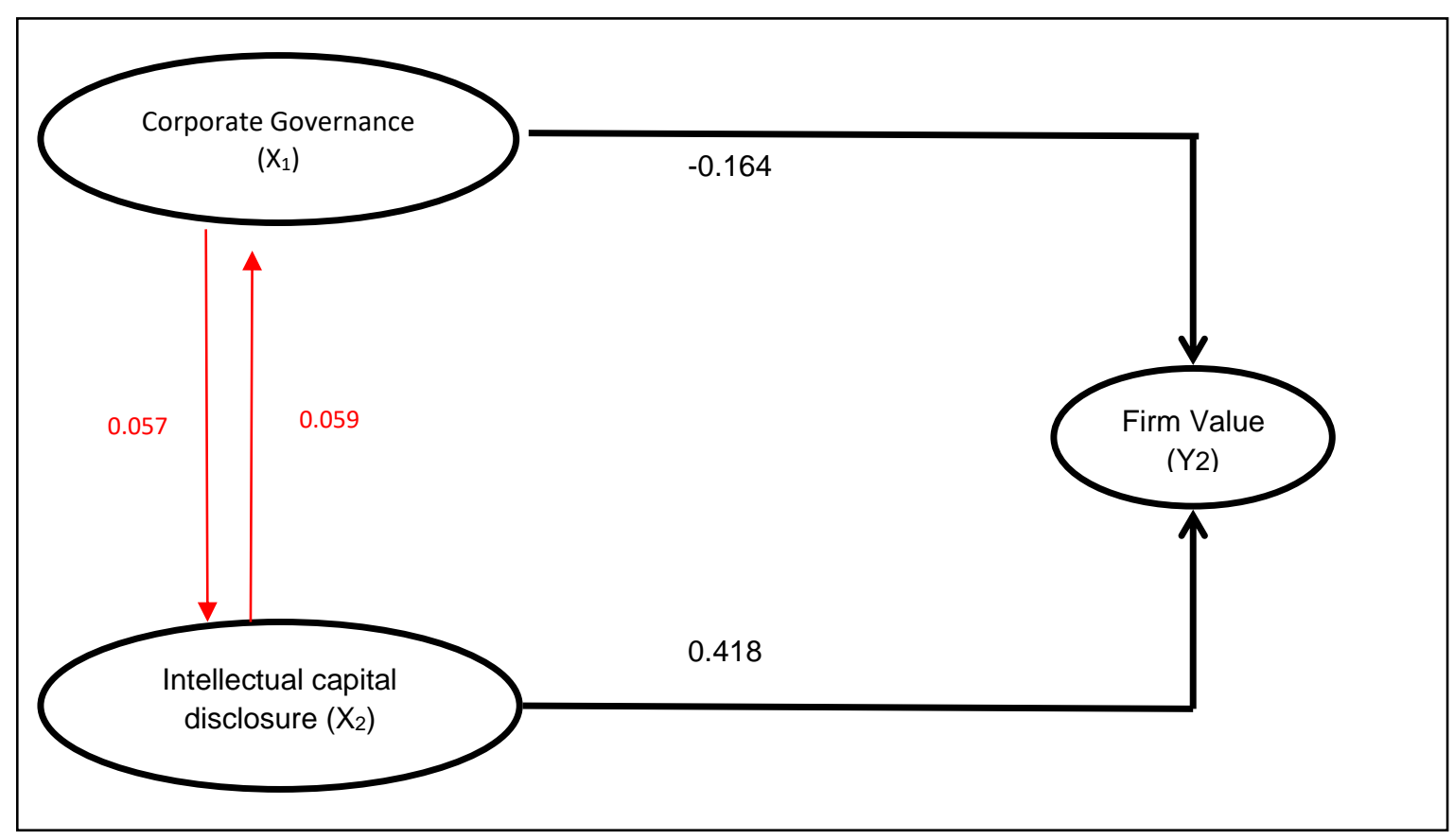

Figure 1. Path Diagram

\section{DISCUSSION}

\section{Effect of Corporate Governance on Intellectual Capital}

Results of analysis generate path coefficient of 0.057 and $P$ 0.282, so it can be said the relationship is non-significant. This means that corporate governance has a significant influence with a positive correlation to intellectual capital disclosure in banking sector companies listed on the Stock Exchange in 2008-2012. Research on corporate governance variables uses indicators of proportion of independent audit committees and the proportion of independent commissioners. Intellectual capital disclosure variable has the following indicators: Value Added Capital Employed (VACA), Value Added Human Capital (VAHU), and Capital Structure Value Added (STVA). These findings are not consistent with the results of several studies [2,10,12,14,32-35] which show that corporate governance and intellectual capital disclosure has a significant influence, and vice versa.
The analysis on the influence of corporate governance on intellectual capital disclosure results in path coefficient 0.057 (5.7\%). Given the path coefficient is positive, it can be said that any changes to the corporate governance variable in the banking sector companies listed on the Stock Exchange do not cause any changes in the variable of disclosure of intellectual capital on the banking sector companies listed on the Stock Exchange.

Corporate governance practices with the indicator proportion of independent audit committee and independent commissioner does not significantly produce positive relationship to intellectual capital. This can be explained that the addition of independent audit committee members and independent board may only to meet the formal provisions, while the majority shareholders (founders) still play an important role, so the performance of the board is not increased [35]. The appointment of an independent audit committee and independent board by the company may only be done for 
regulatory compliance only and is not intended to uphold good corporate governance (GCG) within the company. This condition is also confirmed from the results of a survey of the Asian Development Bank [35] which states that the strong control of the company's founder and majority ownership makes independent audit committee and board of directors are no longer independent. Monitoring function that should be the responsibility of board members may become ineffective, then the performance of the company which is represented in the financial statements has also been ignored, and thus the disclosure of intellectual capital by VAIC approach that is expected to create value-added of companies is not met.

The same explanation is due to the weakness of the implementation of corporate governance in banking sector in Indonesia and small attention of banking sector on intellectual capital [34]. It is because the existence of corporate governance and disclosure of intellectual capital is primarily to comply with Bapepam and just focus on operating performance of the company. Besides, even when viewed from the tendency of the model of corporate governance applied in Indonesia is more directed to follow the implementation model of continental Europe, as some refer to characteristics of the system are: (a) law firm in Indonesia adopts the "French civil-law tradition" of continental Europe; (b) the use of a dual board structure of the company (two-tier board system) as also found in various countries in continental Europe; (c) the concentration of ownership of the company, even when it goes public, on a group of people; (d) the dominant source of corporate financing from outside the company in the form of debt; and (e) illiquid capital markets and the ineffectiveness of control mechanisms by the market [36]. Instead, the application of AngloSaxon model, where capital markets play an important role in the economy, is a mechanism used called the external control system (Outsider control system).

\section{Effect of Intellectual Capital on Corporate Governance}

Result of analysis generates path coefficient of 0.059 and $P$ 0.193, so it can be said to be nonsignificant. This means intellectual capital disclosures has non-significant positive effect on corporate governance in banking sector companies listed on the Stock Exchange in 20082012. The indicators of intellectual capital disclosure are Value Added Capital Employed
(VACA), Value Added Human Capital (VAHU), and capital Structure Value Addedt (STVA). Research on corporate governance variable uses indicators: the proportion of independent audit committee and the proportion of independent commissioners. Researchers in this study tried to study the opposite, the influence of intellectual capital disclosure on corporate governance, particularly in the banking sector companies listed on the Stock Exchange, as a novelty in this study. This finding is the novelty of the research, because no studies have examined the influence of intellectual capitaldisclosure on corporate governance.

The analysis on the effect of intellectual capital disclosure on corporate governance generates path coefficient of 0.059 (5.9\%). Given the path coefficient is positive, it can be said that any changes in the variable of intellectual capital disclosure in the banking sector companies listed on the Stock Exchange will not cause changes in the variable of corporate governance in banking sector companies listed on the Stock Exchange.

Intellectual capital disclosure with VAIC approach does not significantly produce positive relationship to corporate governance. It indicates thatdisclosure of intellectual capital is not an important factor to corporate governance. It is due to the weakness of the implementation of corporate governance in banking sector in Indonesia and small attention of banking sector on intellectual capital [34]. Disclosure of intellectual capital and corporate governance practices are mainly done only to comply with the provisions of Accounting Standards (GAAP) and Bapepam and just focus on the operating performance of the company, so disclosure of intellectual capital with VAIC approach that is expected to create value-added to companies was not met. One of the reasons is due to climatic factors of unstable capital market in 2009 so that companies preferreports related to the performance of companies and the exclusion of voluntary reports [37].

\section{Effect of Corporate Governance on Firm Value}

Results of analysis generates path coefficient of -0.164 and $P 0.00$, so it can be said that corporate governance has significant effect on firm value in banking sector companies listed on the Jakarta Stock Exchange 2008-2012. Corporate governance has significant effect on firm value confirmed by several studies [32,38-45].

Results of the analysis on the influence of corporate governance on firm value generate 
path coefficient of -0.164 or $-16.4 \%$. Given the path coefficient is negative, it means that whenever there is a change in the variable of corporate governance in banking sector companies listed on the Stock Exchange amounted to 1 , there will be decline in the variable of firm value in banking sector companies listed on the Stock Exchange of $16.4 \%$, and the vice versa.

Implementation of corporate governace in banking sector companies listed on the Stock Exchange negatively affects firm value. This indicates the existence of other variables outside the model more positively affect firm value, for example, global economic conditions, government policies, legal certainty, the political situation, and so forth.

Corporate governance practices with the indicator of proportion of audit committee independent and independent commissioner has significant negative effect on firm value. This can be explained that the addition of independent audit committee members and independent board may only to meet the formal provisions, while the majority shareholders (founders) still play an important role, so the performance of the board is not increased [35]. The appointment of an independent audit committee and independent board by the company may only be done for regulatory compliance only and is not intended to uphold good corporate governance (GCG) within the company. This condition is also confirmed from the results of a survey of the Asian Development Bank [35] which states that the strong control of the company's founder and majority ownership makes independent audit committee and board of directors are no longer independent. Monitoring function that should be the responsibility of board members may become ineffective, then the performance of the company represented in the financial statements has also decreased, and thus the firm value the company decreases as well.

Corporate governance variable has not been able to positively affect firm value. Good corporate governance affects the company's stock price in the long term. This may be because the market response to the implementation of corporate governance is not direct, as it will take time. The influence of corporate governance on firm value tends to only be seen in the long term because it is associated with a confidence level of investors. Although in average, the application of corporate governance is quite high, 56\% and 58\% (proportion of independent audit committees and the proportion of independent directors), and gives a positive signal, investors are more concerned with the market response-if signal and market performance seems to produce benefit, investors respond positively, and the vice versa. Moreover, investors still do not trust the CGPI survey results, because with the advent of Bank Century case and BNI, two banks which one were the top 10, a mess of performance happened in the following year. Thus, IICG have to fight hard in order to make CGPI more credible and can be used as an indicator for investors in making investment decisions.

\section{Effect of Intellectual Capital Disclosure on Firm Value}

Results of analysis generates path coefficient of 0.418 and $P 0.00$, so it can be said that the intellectual capital disclosure have significant effect on firm value in anking sector companies listed on the Jakarta Stock Exchange 2008-2012. The significant effect and positive path coefficient means that the disclosure of intellectual capital will improve the financial performance of the banking sector companies listed on the Stock Exchange amounted to $41.8 \%$ and vice versa. The findings of this study are consistent with previous studies [14,46-51].

Disclosure of intellectual capital variable is able to significantly affect firm value. This may be because the market response to the implementation of intellectual capital disclosures can directly be felt. Influence of intellectual capital disclosures on firm value, even though new to the category of the company in general and corporate banking sector in particular, especially using the VAIC (Value Added Intellectual Coefficient), can be seen in the annual financial statements of the company making investors can directly understand the value added of the company itself. To increase firm value or the market value of a company, value added is needed and can be created by developing the company's disclosure of intellectual capital. Good intellectual capital disclosure gives positive signal on the management of a company, the investor will give a positive response, and with a positive response from investors, demand for shares can be expected. Investors will providepositive legitimacy for companies with high disclosure of intellectual capital; in other words, investors will judge that the company that owns and revealing intellectual capital as a whole as a company that has good adherence to regulations from both the government or from other parties [25]. 


\section{Recommendation}

Suggestions for management and practitioners are described as follows. Owners and management of companies are advised to carry out the banking sector business based on the principles of corporate governance and regulations consistently. Likewise, it is advisable to disclose intellectual capital with the approach of Value Added Intellectual Coefficient (VAIC) in accordance with Indonesian accounting standards or international accounting standards.

Practitioners who use the intellectual capital, such as managers, especially in knowledge-based companies, need to know the importance of intellectual capital and knowledge as an important factor affecting the ability of the company to compete in the global market.

Financial Services Authority and the Indonesian Institute of Accountants may set a basic standard and regulations in a particular approach to the disclosure of intellectual capital through Value Added Intellectual Coefficient (VAIC) approach.

\section{CONCLUSION}

Corporate Governance has non-significant effect on intellectual capital in banking sector companieslisted in the Stock Exchange in 20082012. and Intellectual capital disclosure has nonsignificant effect corporate governance in banking sector companieslisted in the Stock Exchange in 2008-2012

Corporate governance has significant effect on firm value in banking sector companies listed on the Stock Exchange in 2008-2012. This mean that the application of the principles of corporate governance (transparency, accountabily, responsibility, independence and fairness)can have a significant yet negative impact on the firm value of banking sector companies listed on the Stock Exchange.

Intellectual capital has significant effect on firm value in banking sector companies listed on the Stock Exchange in 2008-2012. Future researchers are suggested to conduct research on the mutual influence between the corporate governance and intellectual capital in different industries, paying attention to ratings of companies, and researching in banking sector in accordance with the practice of corporate governance index.

Future studies are recommended to include other indicators, such as the proportion of ownership, educational background of commissioner, the number of board meetings, and other.

\section{Acknowledgement}

The author would like to thank Prof. Dr. Suhadak, M.Ec. and Prof. Dr. Endang Siti Astuti, M.Si for developing the analysis of the study.

\section{REFERENCES}

[1]. Al-Musalli Mahfoudh Abdul Karim and Ku Ismail Ku Nor Izah., 2012, "Corporate Governance, Bank Specipic Characteristics, Banking Industry Characteristics, and Intellectual Capital performance of Bank In Arab Gulf Coorpoeration Council (GCC) Countries," Asean Academy of Management Journal of Accounting and Finance, 8 (supp 1), Penerbit Universiti Sains Malaysia, : 115135.

[2]. Ting Kiong Irene Wei dan Lean Hooi Hooi, 2009;. "Intellectual Capital performance of financial institutions in Malaysia,"Journal Intellectual Capital,10.(4), Emeral Group Publishing Limited, 1469-1990, : 588-599

[3]. Bontis, N. 1998. "Intellectual capital: an exploratory study that develops measures and models". Management Decision, 36 (2),: 63-76.

[4]. 2000. "Intellectual Capital and Business Performance in Malaysian Industries,".Journal of Intellectual Capital, 1 (1): 85-100

[5]. Suhardjanto Djoko, Dewi Aryanie, Rahmawati Erna andM. Firzonia, 2012,."Peran Corporate governance dalam praktek Risk Disklosure pada Pebankan Indonesia,"Jornal Akuntansi dan Auditing. 9 (1), : 16-31.

[6]. Ningrum Nora Riyanti dan Shiddiq Nur Rahardjo, (2012), “Analisis pengaruh intellectual capital dan Corporate governance terhadap financial performance, pada perusahaan financial yang terdaftar pada BEJ, " Diponogoro Journal of Accounting " 1 (2), ; 1-15

[7]. Pulic, A. 1998, Measuring the performance of intellectual potential in knowledge economy.available at: www.vaic-on.net 2000, "VAIC - An Accounting Tool for IC Management,".International Journal of Technology Management, 20(5).:702-724.

[8]. Rafinda, A., Pramuka, B., \& Kusuma, P. 2011. Tren dan Variasi Intellectual Capital Disclosure pada Perusahaan-Perusahaan Perbankan di Eropa. Makalah ini 
dipresentasikan pada Simposium Nasional Akuntansi XIV di Aceh

[9]. Van Oorschot, L. 2009. Risk Reporting: An Analysis of German Banking Industry. http://oaithesis.eur.nl. 30 August 2010

[10]. Taliyang Siti Mariana and Jusop Mariana, 2011,."Intellectual Capital Disclosure and Corporate Governance structure : Evidence in Malaysia,"International Journal of Businees and Management, 6 (12), DOI : 10.5539/ijbm.v6n12p109, : 109-117.

[11]. Wu Mei-Fen, Lee Yu-Je and Wang Gao-Liang, 2012,."To Very How Intellectual Capital Affects Organizational Performance in Listed Taiwan IC Companies with Considering the Moderator of Corporate Governance,"The Journal of Global Businees Management, 8 (1),: 20-32.

[12]. Safieddine Assem, Jamali Dima and Noureddine Sarah, 2009,. "Corporate Governance and Intellectual Capital : Evidence from an academic institution, " Corporate Governance.9(2), Emerald Group Publishing Limited, ISSN 1472-0701, DOI : 10.1108/14720700946596, : 146-157.

[13]. Lee Yu-Je, Wu Mei-Fen and Chang ChungMing, 2010, "Using SEM to very the Impacts of Intellectual Capital Accoumulation and Corporate Governance upon Corporate Value : A Case of Taiwan-Listed Information and Electronics Company,"The Journal of Global Businees Management, 8 (1), : 1-12.

[14]. Coleman, Anthony Kyereboah. 2007. Corporate Governance And Firm Performance In Africa - A Dynamic Panel, A Paper Prepared for the "International Conference on Corporate Governance in EmergingMarkets", Organized by the Global Corporate Governance Forum (GCGF) and Asian Institute of Corporate Governance (AICG), 15th -17th November, 2007, Sabanci University, Istanbul, Turkey.

[15]. Tricker, Robert L, 1994, International Corporate Governasnce : text, Reading and Cases, Prentice Hall, Simon \& Schuster (Asia) Pte.Ltd, Singapore.

[16]. Beasley, M.S. (1996). An empirical analysis of the relation between the board of director composition and financial statement fraud. The Accounting Review, 71, 443-65.

[17]. Beasley, M.S. (1996). An empirical analysis of the relation between the board of director composition and financial statement fraud. The Accounting Review, 71, 443-65.
[18]. Eng, L.L. dan Mak Y.T. 2003. "Corporate Governance and Voluntary Disclosure." Journal of Accounting and Public Policy, 22:; 325-345.

[19]. Weston, Fred. J and Thomas, E Copeland. 1997. Manajemen Keuangan : Jilid 2. Jakarta : Binarupa Aksara.

[20]. Patell James M., 1976,. “Corporate Forecasts of Earnings Per Share and Stock Price Behavior, Empirical test", Journal of accounting Research, 14, (2) (Autumn,1976), : 246-276, URL

[21]. Anderson, Ronald C. and David M. Reeb. 2004. Board Composition: Balancing Family Influence in S\&P 500 Firms. Administrative Science Quarterly, Vol. 49, No. 2, pp.209-237

[22]. Wild, J.J. 1994. Managerial Accountability To Shareholders: Audit Committees And The Explanatory Power Of Earnings For Returns, The British Accounting Review, Volume 26, Issue 4, December 1994, Pages 353-374. Stable URL: http://dx.doi.org/10.1006/bare. 1994.1024.

[23]. Klein, April. 2006, Audit committee, board of director characteristics, and earnings management, Journal of Accounting and Economics, Volume 33, Issue 3, August 2002, Pages 375-400. Stable URL: http://dx.doi.org/10.1016/S01654101(02)00059-9 or http://dx.doi.org/10.2139/ssrn. 246674.

[24]. Modigliani, F. and Miller, M. H. (1958) The cost of capital, corporation finance, and the theory of investment,American Economic Review, 48, 261-97

[25]. Salvatore, Dominick. 2005. Managerial Economics, Ekonomi Manajerial dalam perekonomian global, Book 2, Fifth Edition, Salemba Empat Publisher, Jakarta

[26]. Boediono, Gideon SB, 2005, "Kualitas Laba ; Studi Pengaruh Mekanisme Corporate Governance dan Dampak Manajemen Laba dengan menggunakan Analisis Jalu ", Accounting National Symposium VIII, Solo

[27]. Carningsih, 2010, “ Hubungan antara kinerja keuangan dengan nilai perusahaan (Studi kasus pada Perusahaan Property dan Real Estatet yang terdaftar di BEl,Accounting Program, Faculty of Economics, Universitas Gunadarma, Jakarta.

[28]. Falikhatun, Aryani Y Anni and Prabowo Ananto, 2011, "The Effects of Corporate Governance on The Intellectual Capital Disclosure : An Empirical Study from Banking 
Sektor In Indonesia, "Accounting Departement, Economics Fakulty, Universitas Sebelas Maret, SurakartaIndonesia, : 1-29.

[29]. Abdul Wahid Akma Hidayu Dol. Abu Nor Asyikin, Latif Wannoraini Abdul and Smith Malcolm., 2013, "Corporate Governance and Intellectual Capital : Evidence from Public and Private Universities,"Higher Education Studies 3 (1), ISSN 1925-4741: 63-78. 